\title{
Can irisin be used in the follow-up of osteoporosis treatment?
}

\section{İrisin osteoporoz tedavisi takibinde kullanılabilir mi?}

\author{
Esra Demirel ${ }^{1}$, Kadri Yıldız ${ }^{2}$, Kenan Çadırcı ${ }^{3}$
}

\begin{abstract}
Aim: This study aims to investigate the possible roles of irisin as a biomarker in the diagnosis and follow-up of osteoporosis.

Methods: A total of 32 postmenopausal osteoporotic and 23 healthy postmenopausal women were received in this study. Bone mineral densitometry (BMD) measurements were done for all patients and control groups Clinical follow-ups were performed every 3 months. To elicit post-treatment values, at the end of the 12-month follow-up period, all patients underwent BMD and biochemical parameters. Serum irisin concentrations were measured by competitive Enzyme-Linked Immunosorbent Assay (ELISA). The detection range of the used kit was $0.5-30 \mathrm{ng} / \mathrm{ml}$.

Results: T-scores were determined as $-3.28 \pm 0.6$ in the BT group (Before treatment) and $-2.49 \pm 0.7$ in the AT group (After-Treatment), and $-0.7 \pm 0.4$ in the control group (C). Significant differences were observed in $T$ scores between BT and AT ( $<<0.001)$, BT and C $(\mathrm{p}<0.001)$, and AT and C $(\mathrm{p}<0.001)$ statistically. Significan differences were observed between BT and $C(p<0.001)$ and AT and $C(p=0.002)$ statistically. There was no significant difference between BT and AT values $(\mathrm{p}=0.327)$ statistically. At the correlation analysis, irisin was positively correlated with $\mathrm{T}$ score $(\mathrm{p}=0.01, \mathrm{r}=0.25)$ and $25-\mathrm{OH}-\mathrm{D}(\mathrm{p}=0.02, \mathrm{r}=0.23)$, and negatively correlated with development of osteoporosis ( $\mathrm{p}=0.02, \mathrm{r}=-0.23$ ). According to the ROC analysis, irisin levels of $4.1 \mathrm{ng} / \mathrm{m}$ or less can predict pre-treatment osteoporosis with $65.6 \%$ specificity and $60 \%$ sensitivity (AUC: $65.8 \%$, $\mathrm{p}=0.014)$.

Conclusion: We concluded that irisin was a protective factor against osteoporosis. It may be used as a biomarke in the diagnosis of osteoporosis.
\end{abstract}

Keywords: Irisin, osteoporosis, zoledronic acid, biomarker

Öz

Amaç: Bu çalışma, osteoporozun tanı ve takibinde bir biyobelirteç olarak irisinin olası rollerini araştırmayı amaçlamaktadir.

Yöntemler: Bu çalışmaya toplam 32 postmenopozal osteoporotik ve 23 sağlıklı postmenopozal kadın alındı. Tüm hasta ve kontrol gruplarında kemik mineral dansitometri (KMY) ölçümleri yapıldı. Klinik takipler 3 ayda bir yapıldı. Tedavi sonrası değerleri ortaya çıkarmak için 12 aylık takip süresinin sonunda tüm hastalara BMD ve biyokimyasal parametreler uygulandı. Serum irisin konsantrasyonları, rekabetçi Enzyme-Linked Immunosorbent Assay (ELISA) ile ölçüldü. Kullanılan kitin algılama aralığı 0,5-30 ng/ml idi.

Bulgular: T-skorları BT grubunda (Tedavi öncesi) $-3,28 \pm 0,6$, AT grubunda (Tedavi Sonrası) $-2,49 \pm 0,7$ ve kontrol grubunda (C) $-0,7 \pm 0,4$ olarak belirlendi. BT ve AT ( $p<0,001)$, BT ve $K(p<0,001)$ ve AT ve K (p<0,001) arasında $\mathrm{T}$ skorlarında istatistiksel olarak anlamlı farklılıklar gözlendi. BT ile $\mathrm{K}(\mathrm{p}<0,001)$ ve AT ile $\mathrm{K}$ $(\mathrm{p}=0,002)$ arasında istatistiksel olarak anlamlı farklar gözlendi. BT ve AT değerleri arasında istatistiksel olarak anlamlı fark yoktu $(p=0,327)$. Korelasyon analizinde irisin, $T$ skoru $(p=0,01, r=0,25)$ ve 25-OH-D $(p=0,02$, $r=0,23$ ) ile pozitif, osteoporoz gelişimi ile negatif korelasyon gösterdi ( $p=0,02, r=-0,23)$. ROC analizine göre, $4,1 \mathrm{ng} / \mathrm{ml}$ veya daha düşük irisin seviyeleri, \%65,6 özgüllük ve \%60 duyarlılıkla tedavi öncesi osteoporozu öngörebilir (EAA: \%65,8, p=0,014).

Sonuç: İrisinin osteoporoza karşı koruyucu bir faktör olduğu sonucuna vardık. Osteoporoz tanısında biyobelirteç olarak kullanılabilir.

Anahtar kelimeler: İrisin, osteoporoz, zoledronik asit, biyobelirteç.
1 University of Health Sciences, Erzurum Regional Training and Research Hospital, Department of Orthopedics and Traumatology, Erzurum, Turkey. ${ }^{2}$ Kafkas University Faculty of Medicine, Department of Orthopedics and Traumatology, Kars, Turkey

3 University of Health Sciences, Erzurum Regional Training and Research Hospital, Department of Internal Medicine, Erzurum, Turkey.

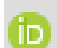

ED: 0000-0002-8468-6286

KY: 0000-0002-8164-7687

KÇ: 0000-0002-2765-4288

Ethics Committee Approval: This study was approved by the Health Sciences University Erzurum Regional Research and Education Hospital with an approval number of 2016-5/18.

Etik Kurul Onayı: Bu çalışma Sağlık Bilimleri Üniversitesi Erzurum Bölge Eğitim ve Araştırma Hastanesi Etik Kurulu tarafindan 2016/5-18 onay numarası ile onaylanmıștır.

Conflict of Interest: No conflict of interest was declared by the authors.

Çıkar Çatışması: Yazarlar çıkar çatışması bildirmemiștir.

Financial Disclosure: The authors declared that this study has received no financial support.

Finansal Destek: Yazarlar bu çalıșma için finansal

destek almadıklarını beyan etmişlerdir.

Geliş Tarihi / Received: 04.04.2021

Kabul Tarihi / Accepted: 27.07.2021

Yayın Tarihi / Published: 02.08.202

Sorumlu yazar / Corresponding author:

Kadri Yildiz

Adres/Address: Kafkas University Faculty of

Medicine, Department of Orthopedics and

Traumatology, Kars, Turkey.

e-mail: dr_2880@hotmail.com

Tel/Phone: +904742252105

Copyright (C) ACEM 


\section{Introduction}

Irisin is a thermogenic protein that exhibits its effect by inducing the conversion of white fat cells into brown fat cells [1]. It is a product of the Pep protein and Fibronectin Type-III Domain 5 (FNDC5) and has been determined to be an important factor in metabolic homeostasis [2]. It also exhibits autogenic, paracrine, and endocrine effects.

Fat serves as a thermogenic and energy storage tissue in the mammalian body, and it has significant effects on the endocrine system [3]. Lipo-blast cells are converted into two different adipose tissues, white and brown (thermogenesis) through diversification into adipocytes. Brown adipose tissue is thought to play a protective role against a decrease in body temperature in infants and affects energy storage, metabolism, and the immune system. This brown adipose tissue has not been in infants only, a small amount of brown adipose tissue has also been in adults. On the other hand, white adipose tissue may be regarded as the largest endocrine tissue in adults. Leptin, ghrelin, glucocorticoids, plasminogen activator inhibitor (PAI-1), TNF- $\alpha$, IL-6, angiotensin, visfatin, resistin, irisin, and many other cytokines are secreted from adipose tissue and are basic compounds affecting metabolism [4]. These molecules, with important roles in communication between organs in the maintenance of metabolic homeostasis and that lead to various metabolic diseases in case of dysfunction, are known as adipocytokines [5].

Osteoporosis, one of the metabolic disorders that threaten the human body, is a common metabolic bone disease characterized by impaired bone mass and bone microarchitecture and eventually an increased risk of fracture. It seems like irisin is a potential junction molecule on the metabolism of obesity and osteoporosis. Recently, Morgan et al concluded that irisin treatment in the ovariectomized rats protected the bone architecture. They declared irisin as a possible target in the prohibition of postmenopausal osteoporosis [6].

The research questions of the study were as follows: i) irisin has a potential bio-marker features to follow up for osteoporosis, ii) in the metabolic pathway, there may be a protective role of irisin against to bone fractures, iii) irisin may be accepted as both diagnostic biomarker and therapeutic agent, and iv) irisin is a junctional molecule between osteoporosis and obesity metabolism.

The purpose of this study was to investigate whether irisin is capable of use as a marker of the follow-up osteoporosis treatment. The main aim was to search for the role of irisin as a biomarker in the diagnosis of osteoporosis.

\section{Material and methods}

This study was planned as a prospective case-control study on the follow-up of the irisin treatment for osteoporosis. The study was approved by the Local Ethics Committee (Erzurum Regional Research and Education Hospital, 2016/5-18) and was by the Declaration of Helsinki and the International Conference on Harmonization for Good Clinical Practice. Written informed consent was obtained from all patients.

For preventing potential sources of bias that might affect the study, all bone mineral densitometry (BMD) measurements, biochemical tests, and statistical analyses were made blinded. The patient group included postmenopausal women between the ages of fifty-five and seventy who applied to the internal medicine and orthopedics outpatient clinics between April and December 2016 and were diagnosed with osteoporosis (T score <-2.5).

Postmenopausal women between the ages of fifty-five and seventy who were not diagnosed with osteoporosis ( $\mathrm{T}$ score $\geq-1$ ) were recruited into the control group. All participant diagnoses were based on their BMD measurements. Three groups were created as Before Treatment (BT), After Treatment (AT), and Control (C) groups.

Inclusion criteria for the patient group were diagnosis of osteoporosis, no previous receipt of treatment for osteoporosis, and absence of any systemic or localized disease. Exclusion criteria were receipt of any surgical procedure during the study, the detection at follow-up during the study of any systemic disease requiring medication use, or the impossibility of clinical follow-up. Twenty-three postmenopausal women with no metabolic or systemic disease, including osteoporosis and osteopenia at BMD measurements, with no recent history of major surgery/disease, were included as the control group.

All patients included in the study and providing blood specimens received a single intravenous $5 \mathrm{mg} / 100 \mathrm{ml}$ dose of Zoledronic Acid (Novartis Pharma Stein AG, Stein, Switzerland). These patients underwent three-monthly clinical follow-ups. The 32 patients remaining at the end of the 12-month follow-up period underwent BMD to elicit post-treatment values. Various biochemical values were again investigated posttreatment.

For pre-treatment irisin measurements, $10 \mathrm{cc}$ venous blood specimens were collected between 07:30 and 09:30 am following 12-h overnight fasting. These were centrifuged for 10 min at $4000 \mathrm{rpm}$ using an Electromag M4808 P Centrifuge device and stored at $-80^{\circ} \mathrm{C}$. The same procedure was performed to determine post-treatment irisin values, and blood specimens collected from the 32 patients were centrifuged and stored at $80^{\circ} \mathrm{C}$.

Serum irisin concentrations were measured by competitive ELISA (Enzyme-Linked ImmunoSorbent Assay) (Eastbiopharm Company, Shangai) according to the manufacturer's instructions. The detection range of the kit was 0.5-30 ng/ml. Patients' BMD measurements were performed using a D.M.S STRATOS bone densitometry device (France) with dual X-ray absorptiometry (DXA). Routine biochemical parameters, vitamin, parathormone $(\mathrm{PTH})$, and TSH were measured on an Abbott Architect i2000 SR device using the Chemiluminescent Microparticle Immunoassay (CMIA) method.

\section{Statistical analysis}

Statistical analyses were performed on SPSS 19.0 (Windows) software. The variables were normally distributed according to the presentation with mean $\pm \mathrm{SD}$. The student's t-test and the Mann-Whitney $U$ test were applied for comparisons. Kruskal Wallis H Test was used for correlation analysis between categorical and numerical values. Pearson's correlation test and the Spearman correlation test were applied to determine relations between variables. ROC analysis was performed to determine a cut-off value for irisin. $\mathrm{P}$ values less than 0.05 were regarded as statistically significant.

\section{Results}

A total of 32 postmenopausal osteoporotic and 23 healthy postmenopausal women were received. The mean age of the groups was $62.5 \pm 7.5$ years in the patient group and $60.0 \pm 4.5$ years in the control group $(\mathrm{p}=0.054)$. Mean BMI values were 
$29.0 \pm 3.5 \mathrm{~kg} / \mathrm{m}^{2}$ in the patient group and $31.1 \pm 3.9 \mathrm{~kg} / \mathrm{m}^{2}$ in the control group $(\mathrm{p}=0.240)$

Table 1. Clinical and biochemical characteristics of the patient and control groups.

\begin{tabular}{lccc} 
& $\begin{array}{c}\text { Patients } \\
(\mathbf{n}=\mathbf{3 2})\end{array}$ & $\begin{array}{c}\text { Controls } \\
(\mathbf{n = 2 3})\end{array}$ & $\mathrm{p}$ \\
\hline Age $(\text { year })^{\dagger}$ & $62.5 \pm 7.5$ & $0.0 \pm 4.5$ & 0.054 \\
$\mathrm{BMI}\left(\mathrm{kg} / \mathrm{m}^{2}\right)^{\dagger}$ & $29.2 \pm 3.5$ & $1.1 \pm 3.9$ & $>0.05$
\end{tabular}

\begin{tabular}{lcccccc} 
& B T & AT & C & $\mathbf{p}_{1}$ & $\mathbf{p}_{2}$ & $\mathbf{p}_{3}$ \\
\hline T score $^{\dagger}$ & $-3.2 \pm 0.6$ & $-2.4 \pm 0.7$ & $0.7 \pm 0.4$ & $<0.001$ & $<0.001$ & $<0.001$ \\
Irisin $(\mathrm{ng} / \mathrm{ml})^{\dagger}$ & $5.23 \pm 6.08$ & $6.03 \pm 5.19$ & $6.70 \pm 3.34$ & $<0.001$ & 0.002 & 0.002 \\
$25-\mathrm{Hydroxy}$ vitamin D $(\mathrm{ng} / \mathrm{ml})^{\dagger}$ & $12.9 \pm 11.5$ & $17.4 \pm 15.0$ & $3.6 \pm 21.0$ & 0.010 & $>0.05$ & $>0.05$ \\
$\mathrm{PTH}(\mathrm{pg} / \mathrm{ml})^{\dagger}$ & $108.1 \pm 87.7$ & $89.7 \pm 64.4$ & $63.5 \pm 26.4$ & 0.008 & $>0.05$ & $>0.05$ \\
$\mathrm{TSH}(\mu \mathrm{IU} / \mathrm{mL})^{\dagger}$ & $1.3 \pm 0.9$ & $1.2 \pm 0.7$ & $0.0 \pm 1.8$ & $>0.05$ & $>0.05$ & $>0.05$ \\
$\mathrm{Creatinin}^{\dagger}(\mathrm{mg} / \mathrm{dl})^{\dagger}$ & $0.7 \pm 0.1$ & $0.8 \pm 0.1$ & $0.7 \pm 0.1$ & $>0.05$ & $>0.05$ & $>0.05$ \\
$\mathrm{Calcium}(\mathrm{mg} / \mathrm{dl})^{\dagger}$ & $9.1 \pm 0.7$ & $9.0 \pm 0.7$ & $9.4 \pm 0.4$ & $>0.05$ & $>0.05$ & $>0.05$ \\
$\mathrm{Phosphorus}(\mathrm{mg} / \mathrm{dl})^{\dagger}$ & $3.45 \pm 0.5$ & $3.3 \pm 0.5$ & $3.4 \pm 0.8$ & $>0.05$ & $>0.05$ & $>0.05$ \\
$\mathrm{ALP}(\mathrm{U} / \mathrm{L})^{\dagger}$ & $97.7 \pm 51.2$ & $80.7 \pm 32.4$ & $84.8 \pm 28.4$ & $>0.05$ & $>0.05$ & $>0.05$ \\
$\mathrm{CK}(\mathrm{U} / \mathrm{L})^{\dagger}$ & $96.4 \pm 85.5$ & $71.4 \pm 20.6$ & $92.9 \pm 37.4$ & $>0.05$ & $>0.05$ & $>0.05$
\end{tabular}

: mean standard \pm deviation

BT: before treatment, AT: after treatment, C: controls, BMI: Body Mass Index, PTH: Parathormone, TSH: Thyroid -Stimulating Hormone, ALP: Alkaline phosphatase, CK: Creatinine kinase.

$\mathrm{p}_{1:}$ statistically relationship between before treatment and controls

$\mathrm{p}_{2}$ : statistically relationship between after treatment and controls.

$\mathrm{p}_{3:}$ statistically relationship between before treatment and after treatment.

Pre-treatment and post-treatment biochemical data, $\mathrm{T}$ scores, and irisin levels in the patient group were examined and subjected to statistical analysis as BT, AT, and C groups. T scores were $-3.28 \pm 0.6,-2.49 \pm 0.7$, and $-0.7 \pm 0.4$ in the groups of BT, AT, and C, respectively. Irisin levels were $5.23 \pm 6.08 \mathrm{ng} / \mathrm{ml}$, $6.03 \pm 5.19 \mathrm{ng} / \mathrm{ml}$, and $6.70 \pm 3.34 \mathrm{ng} / \mathrm{ml}$ in the groups of BT, AT, and $\mathrm{C}$, respectively. Clinical and biochemical values in the study groups and the Group $\mathrm{C}$ are shown in Table 1.

Statistically significant differences were observed in $\mathrm{T}$ scores between the groups BT and C $(\mathrm{p}<0.001)$. Statistically significant differences were observed between the groups of BT and $\mathrm{C}(\mathrm{p}<0.001)$.

Statistically significant differences were observed in $\mathrm{T}$ scores between BT and AT groups $(\mathrm{p}<0.001)$, and AT and C groups $(\mathrm{p}<0.001)$. Statistically significant differences were observed between the groups of between AT and C $(p=0.002)$ groups, and BT and AT ( $\mathrm{p}=0.002)$ groups.

At correlation analysis, irisin was positively correlated with $\mathrm{T}$ score $(\mathrm{p}=0.01, \mathrm{r}=0.25)$ and $25-\mathrm{OH}-\mathrm{D}(\mathrm{p}=0.02, \mathrm{r}=0.23)$, and negatively correlated with development of osteoporosis $(\mathrm{p}=0.02, \mathrm{r}=-0.23)$. Correlation analysis data are shown in Table 2. Development of osteoporosis was positively correlated with age $(\mathrm{p}=0.003, \mathrm{r}=0.312)$ and PTH $(\mathrm{p}=0.001, \mathrm{r}=0.352)$, and negatively correlated with $\mathrm{T}$ score $(\mathrm{p}=0.000, \mathrm{r}=-0.868)$ and 25 OH-D $(p=0.01, r=-0.26)$. There was no correlation between other parameters.

Table 2. Correlation analysis between the irisin and other parameters.

\begin{tabular}{lcc}
\hline T score & 0.01 & 0.25 \\
25-Hydroxy vitamin D & 0.02 & 0.23 \\
Osteoporosis development & 0.02 & -0.23 \\
\hline
\end{tabular}

ROC analysis showed that irisin is a useful marker for predicting the diagnosis of osteoporosis and follow-up treatment. According to the ROC analysis, irisin levels of $4.1 \mathrm{ng} / \mathrm{ml}$ or less can predict osteoporosis with $65.6 \%$ specificity and $60 \%$ sensitivity (AUC: 65.8\%, p=0.014) (Figure 1).

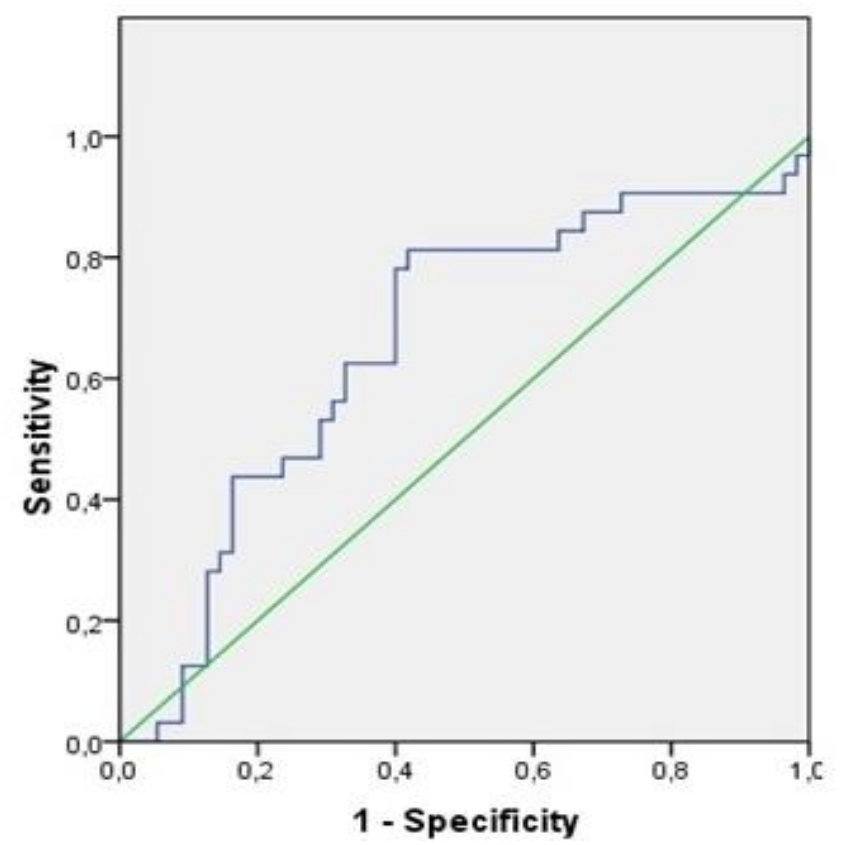
the treatment.

Figure 1. The irisin levels for predicting osteoporosis before 


\section{Discussion}

According to our results, the mean age was $6^{\text {th }}$ decade. There was no significant difference between groups. The mean $\mathrm{BMI}$ values were similar in groups. In BT, AT, and $\mathrm{C}$ groups, irisin levels were $5.23 \pm 6.08 \mathrm{ng} / \mathrm{ml}, 6.03 \pm 5.19 \mathrm{ng} / \mathrm{ml}$, and $6.70 \pm 3.34 \mathrm{ng} / \mathrm{ml}$, respectively. There was significant difference statistically between BT, AT and C groups, in pairwise comparisons between groups. We found that irisin was positively correlated with $\mathrm{T}$ scores, and and negatively correlated with development of osteoporosis. Development of osteoporosis was positively correlated with age, and negatively correlated with $\mathrm{T}$ score. According to our ROC analysis, the specificity was $65.6 \%$ and the sensitivity was $60 \%$, when irisin levels of $4.1 \mathrm{ng} / \mathrm{ml}$ or less.

Recent findings have shown that irisin affects both bone and glucose metabolism in humans. Irisin is an adipokine directly associated with obesity and glucolipid metabolism and increases cortical bone mass by affecting the osteoblast metabolic pathways $[7,8]$. In vitro data from one study showed that the myokine irisin can affect bone metabolism by encouraging osteoblast differentiation [9].

One study examined the relation between irisin and bone metabolism in a Chinese population $(n=6,308)$. Irisin levels were significantly higher in this population. A positive relation was determined between plasma irisin levels and BMD in elderly individuals [10]. Another study examined the relationship between BMD values and irisin levels in 160 Chinese women who were 70-90 years old. In addition, the irisin values were detected significantly lower in osteoporotic and osteopenic women compared to the control group, the low irisin levels in women were associated with an increased rate of femoral neck fracture and the lumbar spine fracture [11].

The basic aim of Palermo A et al.'s study [12] was to investigate the association between irisin and body composition in postmenopausal women with osteoporosis and to examine the effect of irisin on brittleness and vertebra fractures. Their databases confirmed an inverse correlation between irisin levels and vertebral osteoporotic fractures, but no significant relation was determined with BMD or non-fat mass. In another study, irisin levels in circulation were associated with previous osteoporotic fractures, but not with bone mass, and were not affected by 3-month denosumab (Dmab) or teriparatide (TPTD) therapy. That study was intended to investigate irisin levels in the circulation in postmenopausal women with low bone mass and the potential effects of three-month Dmab or TPTD therapy. No difference was determined in serum irisin levels between women with or without low bone mass, and these were unaffected by three-month Dmab or TPTD therapy. Irisin levels in circulation were found to be associated with previous osteoporotic fractures. However, the study was unable to conclude whether this relation was independent of whether or not it potentially derived from low bone mass reflected by low creatinine levels [13].

Physical activities such as sports are known to have a positive effect on BMD. A study from Italy, including members of the Bari soccer team, determined a positive correlation between BMD and irisin. The irisin levels of circulation were related to the improving Z-scores. From that perspective, irisin which is a myokine could be described as a 'sports hormone' [14]. One experimental mouse study reported that irisin has a positive effect on cortical bone mass, bone strength, and periosteal circulation. This anabolic effect, stimulation of bone formation, is independent of osteoclast activity. As anticipated, a low dose of r-irisin modulated the skeleton genes, Opn and Sost, rather than Ucp1 or Ppar gamma expression in white adipose tissues. Although the irisin precursor FNDC5 is abundantly expressed in skeletal muscle, other regions such as bone and brain have also been found to express FNDC5 at low levels. In addition, increased FNDC5 positivity and increased expression of FNDC5 mRNA were shown in muscle fibers in mice that were injected r-irisin [15].

It was known that irisin is a molecule linked to Type 2 Diabetes Mellitus, lipid metabolism disorders, cardiovascular diseases, non-alcoholic fatty liver, polycystic ovarian syndrome, and metabolic bone diseases. In addition, in terms of metabolic bone diseases, irisin is directly related to BMD and athletic performance. Irisin may be in the future a therapeutic target in metabolic bone diseases $[16,17]$.

Irisin has a pathophysiologic corner point in metabolic diseases. Also, it has therapeutic targets for metabolic pathways [18]. Briganti SI et al declared the regulator role of irisin in both bone and glucose metabolism [19]. Sarcopenia has a pioneering role before osteopenia. $\mathrm{Li} \mathrm{G}$ et al emphasized the roles of various factors affecting muscle bone crosstalk and potential therapeutic approaches. They decided that irisin has an important role in the muscle-bone crosstalk and potential therapies for sarcoosteoporosis [20]. In another study, Xu L et al. [21] searched the effects of irisin on osteoblast apoptosis and osteoporosis in postmenopausal osteoporosis rats. They found that irisin inhibited the incidence of apoptosis, but also treated postmenopausal OP through upregulating Nrf2 and inhibiting NLRP3 expression. Notable for her work on irisin, Colaianni G emphasized that irisin has a key player in bone metabolism and its role is emerging as a possible therapeutic option to treat bone diseases [22]. In the growing rats, HFD has negative effects on $\mathrm{BMD}$, bone microstructure, and bone metabolism. Swimming exercise decreased body weight, body fat, and pro-inflammatory cytokines. The swimming exercises increased serum irisin levels and expression of PGC-1/FNDC5 in the bone. This study advocated that swimming can improve bone microstructure, even if a high-fat diet [23].

The limitations of this study may be listed as follow: i) the number of patients in the group we used in the study could have been higher, ii) the study could be a comprehensive metaanalysis involving multiple medical centers with a larger number of patients, iii) since irisin is a junction molecule in human metabolism, other bio-regulatory compounds associated with metabolism and irisin could also be investigated in the blood material taken for our study.

Irisin level may be used as a marker in the diagnosis of osteoporosis. A significant difference was determined in irisin levels between before and after the treatment we think that further studies are now needed concerning the potential use of irisin as a parameter in the follow-up of osteoporosis treatment and maybe treatment agent.

\section{References}

1. Kelly DP. Medicine. Irisin, light my fire. Science. 2012;6077;42-3.

2. Boström P, Wu J, Jedrychowski MP, Korde A, Ye L, Lo JC, et al. A PGC1- $\alpha$-dependent myokine that drives brown-fat-like development of white fat and thermogenesis. Nature. 2012;481:463-8.

3. Kershaw EE, Flier JS. Adipose tissue is an endocrine organ. J Clin Endocrinol Metab. 2004;89:2548-56.

4. Coelho M, Oliveira T, Fernandes R. Biochemistry of adipose tissue: an endocrine organ. Arch Med Sci. 2013;9:191-200.

5. Cao H. Adipocytokines in obesity and metabolic disease. J Endocrinol. 2014;220:47-59. 
6. Morgan EN, Alsharidah AS, Mousa AM, Edrees HM. Irisin Has a Protective Role against Osteoporosis in Ovariectomized Rats. Biomed Res Int. 2021;Apr 26;2021:5570229.

7. Al-Daghri NM, Mohammed AK, Al-Attas OS, Amer OE, Clerici M, Alenad A, et al. SNPs in FNDC5 (irisin) are associated with obesity and modulation of glucose and lipid metabolism in Saudi subjects. Lipids Health Dis. 2016;15:54.

8. Briganti SI, Gaspa G, Tabacco G, Naciu AM, Cesareo R, Manfrini $S$, et al. Irisin as a regulator of bone and glucose metabolism. Minerva Endocrinol. 2018;43:489-500.

9. Qiao X, Nie Y, Ma Y, Chen Y, Cheng R, Yin W, et al. Irisin promotes osteoblast proliferation and differentiation via activating the MAP kinase signaling pathways. Sci Rep. 2016;6:18732.

10. Wu LF, Zhu DC, Tang CH, Ge B, Shi J, Wang BH, et al. Association of plasma irisin with bone mineral density in a large Chinese population using an extreme sampling design. Calcif Tissue Int. 2018;103:246-51.

11. Yan J, Liu HJ, Guo WC, Yang J. Low serum concentrations of irisin are associated with increased risk of hip fracture in Chinese older women. Joint Bone Spine. 2018;85:353-58.

12. Palermo A, Strollo R, Maddaloni E, Tuccinardi D, D'Onofrio $\mathrm{L}$, Briganti SI, et al. Irisin is associated with osteoporotic fractures independently of bone mineral density, body composition, or daily physical activity. Clin Endocrinol (Oxf). 2015;82:615-9.

13. Anastasilakis AD, Polyzos SA, Makras P, Gkiomisi A, Bisbinas I, Katsarou A, et al. Circulating irisin is associated with osteoporotic fractures in postmenopausal women with low bone mass but is not affected by either teriparatide or denosumab treatment for 3 months. Osteoporos Int. 2014;25:1633-42.

14. Colaianni G, Notarnicola A, Sanesi L, Brunetti G, Lippo L, Celi M, et al. Irisin levels correlate with bone mineral density in soccer players. J Biol Regul Homeost Agents. 2017;31(4 suppl 1):21-8.

15. Colaianni G, Cuscito C, Mongelli T, Pignataro P, Buccoliero $\mathrm{C}$, Liu $\mathrm{P}$, et al. The myokine irisin increases cortical bone mass. Proc Natl Acad Sci USA. 2015;112:12157-62.

16. Polyzos SA, Anastasilakis AD, Efstathiadou ZA, Makras P, Perakakis N, Kountouras J, et al. Irisin in metabolic diseases. Endocrine. 2018;59:260-74.

17. Engin-Üstün Y, Çağlayan EK, Göçmen AY, Polat MF. Postmenopausal osteoporosis is associated with serum chemerin and irisin but not with apolipoprotein M levels. J Menopausal Med. 2016;22:76-9.

18. Polyzos SA, Anastasilakis AD, Efstathiadou ZA, Makras P, Perakakis N, Kountouras J, Mantzoros CS. Irisin in metabolic diseases. Endocrine. 2018;59:260-74.

19. Briganti SI, Gaspa G, Tabacco G, Naciu AM, Cesareo R, Manfrini S, Palermo A. Irisin as a regulator of bone and glucose metabolism. Minerva Endocrinol. 2018;43:489-500.

20. Li G, Zhang L, Wang D, AIQudsy L, Jiang JX, Xu H, Shang P. Muscle-bone crosstalk and potential therapies for sarcoosteoporosis. J Cell Biochem. 2019;120:14262-73.

21. Xu L, Shen L, Yu X, Li P, Wang Q, Li C. Effects of irisin on osteoblast apoptosis and osteoporosis in postmenopausal osteoporosis rats through upregulating Nrf2 and inhibiting NLRP3 inflammasome. Exp Ther Med. 2020;19:1084-90.

22. Colaianni G, Sanesi L, Sterling G, Brunetti G, Colucci S, Grano M. Irisin and Bone: From Preclinical Studies to the Evaluation of Its Circulating Levels in Different Populations of Human Subjects. Cells. 2019;8:451.

23. Kang YS, Kim JC, Kim JS, Kim SH. Effects of Swimming Exercise on Serum Irisin and Bone FNDC5 in Rat Models of High-Fat Diet-Induced Osteoporosis. J Sports Sci Med. 2019;18:596-603. 